\title{
Instytucja mediacji w Chińskiej Republice Ludowej i Republice Chińskiej (Tajwanie)
}

\section{Wprowadzenie}

Mediacja w wielu państwach stanowi alternatywę dla postępowania sądowego albo funkcjonuje w jego ramach jako szczególne rozwiązanie procesowe, nie odbierając jednocześnie jednostkom prawa do sądu. Instytucję mediacji, podobnie jak inne chińskie rozwiązania normatywne, należy przy tym postrzegać nie tylko w kontekście prawa stanowionego Chińskiej Republiki Ludowej i Republiki Chińskiej (Tajwanu), lecz także na tle podstawowych założeń konfucjanizmu oraz - jakkolwiek w mniejszym stopniu - taoizmu i buddyzmu ${ }^{1}$. Analiza jakiegokolwiek rozwiązania prawnego nie jest bowiem w pełni możliwa bez poznania jego genezy oraz uwarunkowań historycznych, społecznych, kulturowych i podstawowych założeń politycznych systemu prawnego, w jakim rozwiązanie to funkcjonuje.

Należy też podkreślić, że procedury pojednawcze (zarówno sądowe, jak i pozasądowe) określa się w języku chińskim jako tiaojie (调 解), co może być tłumaczone zarówno jako "mediacja”, jak i "koncyliacja”2.

${ }^{1}$ Na temat znaczenia taoizmu i buddyzmu dla chińskich rozwiązań prawnych zob. m.in. M. Dargas, Idee i zasady konstytucyjne chińskiego porzadku prawnego, Warszawa 2017, s. 63 i n. oraz 80 i n.

${ }^{2}$ P. Chi Hin Chan, The Position of Mediation in Contemporary Chinese Civil Justice: A Proceduralist Perspective, rozprawa doktorska, Maastricht 2016, s. 7; Y. Bu, X. Huo, The Revival of ADR in China: The Path to Rule of Law or the Turn Against Law?, w: New Developments in Civil and Commercial Mediation. Global Comparative Perspectives, C. Esplugues, ed. by L. Marquis, Basel 2015, s. 191. 
Celem niniejszego artykułu jest przedstawienie podstawowych uwarunkowań społeczno-filozoficznych oraz rozwiązań prawnych w zakresie mediacji w Chińskiej Republice Ludowej i w Republice Chińskiej (Tajwanie). Opracowanie nie obejmuje jednak zagadnień med-arbu, który ma cechy zarówno mediacji, jak i arbitrażu, a strony najpierw próbują rozwiązywać swoje spory w drodze mediacji. Jeśli nie przyniesie to rozwiązania, proces ten przechodzi w wiążący arbitraż $\dot{z}^{3}$ W niniejszym artykule w szczególności chodzi o podkreślenie własnych, oryginalnych rozwiązań chińskich i tajwańskich - w znacznym stopniu odmiennych od regulacji tzw. zachodniego systemu prawnego ${ }^{4}$. Rozwiązania te doskonale funkcjonują w praktyce, co - jak podkreślają zarówno chińscy, jak i europejscy badacze - wynika z ich głębokiego osadzenia w tradycjach społecznych i filozoficznych Chin. Uzupełniająco wskazano również na inspiracje porządkiem prawnym Japonii, co w szczególności dotyczy Tajwanu.

Rozważania rozpoczynają uwagi na temat znaczenia konfucjanizmu (a w pewnym stopniu także buddyzmu i taoizmu) dla rozwoju i znaczenia mediacji oraz postrzegania statusu jednostki w państwie i w porządku prawnym obu państw. Następnie przedstawiono krótki rys historyczny mediacji na terenach dzisiejszej ChRL, omówiono podstawowe założenia mediacji ludowej, mediacji i arbitrażu w zakresie sporów wynikających z umów dotyczących gruntów rolnych oraz w zakresie sporów pracowniczych. Nie pominięto również wskazania powodów, dla których chiński i tajwański ustawodawca nie uregulował prawnie możliwości rozstrzygania sporów w postępowaniu administracyjnym i sądowoadministracyjnym. Podkreślono także rolę, jaką odgrywała (i odgrywa nadal) instytucja xinfang (najogólniej, obejmująca: skargi, wnioski i petycje), będąca najpoważniejszym konkurentem dla działań kodyfikacyjnych w zakresie procedury administracyjnej oraz mediacji na jej gruncie. Rozważania zamyka analiza mediacji na Tajwanie, będącej swoistym połączeniem tradycji Chin kontynentalnych, rozwiązań japońskich oraz własnego dorobku prawnego.

${ }^{3}$ Zob. szerzej m.in. K.M. Blankley, Keeping a Secret from Yourself? Confidentiality when the Same Neutral Serves Both as Mediator and as Arbitrator in the Same Case, "Baylor Law Review" 2011, nr 63, s. 370 i n.

${ }^{4}$ Przez "zachodni system prawny” w Chinach i na Tajwanie rozumie się prawo Europy kontynentalnej oraz rozwiązania anglo-amerykańskie. Tay-Sheng Wang, The Legal Development of Taiwan in the 20th Century: Toward Liberal and Democratic Country, "Pacific Rim Law \& Policy Journal Association" 2002, vol. 11, no. 3, s. 531-532. 


\section{Znaczenie konfucjanizmu dla rozwoju instytucji mediacji w Chinach}

\subsection{Uwagi ogólne}

Charakterystyczne dla systemu prawnego Chin przed rokiem 1949 jest silne odwoływanie się do założeń konfucjanizmu, który stał się doktryną imperialną za panowania dynastii Han (206 p.n.e. - 220 n.e.). Konfucjanizm - najogólniej - stanowi zbiór idei przede wszystkim Konfucjusza (孔子), ale także jego następców, takich jak m.in. Mencjusz (孟子), Xunzi (荀), czy Dong Zhongshu (董仲舒) $)^{5}$.

Wpływ tzw. zachodniego systemu prawnego na tradycyjne prawo chińskie rozpoczął się po roku 1840, kiedy zaczęto tłumaczyć teksty prawne oraz opracowania naukowe, głównie z zakresu prawa karnego i cywilnego, a także europejskie pomniki myśli prawnej, jak Umowa społeczna Rousseau czy O duchu praw Monteskiusza ${ }^{6}$. Proces ten nasilił się w okresie Republiki Chińskiej (1912-1949). Akty normatywne tego okresu silnie wzorowały się na rozwiązaniach państw Europy Zachodniej i Stanów Zjednoczonych oraz na prawie japońskim ${ }^{7}$. Zasadnicza zmiana nastąpiła w okresie od 1949 r. do początku lat sześćdziesiątych XX w., kiedy to Chiny kontynentalne odrzuciły dawny system prawny i próbowały ustanowić porządek socjalistyczny, wzorując się na prawie Związku Radzieckiego ${ }^{8}$. Recepcja prawa zachodniego następowała ponownie stopniowo po roku 1978. Natomiast od czasu reform Deng Xiaopinga (邓小平) konfucjanizm przeżywa w Chinach swój renesans ${ }^{9}$, jako "nowy konfucjanizm” (na Tajwanie nazywany „Współczesnym Nowym Konfucjanizmem”, w Chinach kontynentalnych zaś - „Nowożytnym Nowym Konfucjanizmem"). Nowy konfucjanizm kształtował się u progu XX w. w związku z zetknięciem się Chin z wpływem innych światowych systemów filozoficznych oraz chrześcijaństwa. Propaguje

${ }^{5}$ M. Kania, Wptyw konfucjanizmu na ksztattowanie się systemu prawa w Chinach, Wrocław 2012, s. 183.

${ }^{6}$ L. Zhang, Prawo porównawcze w Chinach, „Forum Prawnicze” 2014, nr 5(25), s. 5.

${ }^{7}$ Ibidem, s. 8.

${ }^{8}$ Ibidem, s. 12.

${ }^{9}$ Zob. m.in. A. Skóra, Procedura wnoszenia skarg, wniosków i petycji w Chinach (xinfang). Fenomen zjawiska prawnego i jego stosunek do systemu sądowej kontroli administracji, w: Skargi, wnioski i petycje - powszechne środki ochrony prawnej, pod red. M. Błachuckiego, G. Sibigi, Wrocław 2017, s. 206. 
on syntezę elementów tradycyjnego konfucjanizmu w postaci społecznej, ekologicznej i politycznej harmonii ${ }^{10}$.

Z kolei na Tajwanie zwycięstwo Chen Shui-biana w wyborach prezydenckich zmieniło zasadniczo podejście organów państwa do miejscowej tradycji. Chen Shui-bian oparł swoją filozofię rządzenia na uznawaniu i realizacji wartości zachodnich. Jak deklarował, „demokracja i wolność są wartościami, które przetrwają na zawsze", dlatego potrzebne było m.in. ograniczenie władzy państwa i zmiana zasadniczych jego koncepcji: państwo z "przywódcy i zarządcy” powinno przekształcić się w "dostarczyciela usług” obywatelom, zaś "każdy funkcjonariusz publiczny powinien stać się aktywistą praw człowieka”, tak by "Republika Chińska stała się wzorcem respektowania praw człowieka w XXI wieku"11.

\subsection{Konfucjanizm a system prawa i status jednostki}

Charakterystyczne dla Chin kontynentalnych i Tajwanu ${ }^{12}$ (podobnie jak dla Korei czy Wietnamu $)^{13}$, jako państw dumnych ze swej kultury prawnej, jest odmienne od naszego spojrzenie na prawa jednostki i jej pozycję w społeczeństwie, na porządek społeczno-prawny oraz na rozwiązywanie sporów między jednostkami. Przez wieki bowiem chińska tradycja prawna przedstawiała porządek społeczno-prawny jako dominujący nad indywidualną autonomią jednostki, a w feudalnym społeczeństwie, pod władzą cesarską, przywiązywała szczególną wagę do interesów społeczności czy interesów państwowych kosztem interesu jednostki ${ }^{14}$.

Nietrudno zauważyć, że taki sposób postrzegania statusu jednostki odbiega od założeń zachodniego systemu prawnego i jego tradycji

${ }^{10}$ Zob. szerzej m.in. M. Dargas, Idee i zasady ..., s. 54 i n.; K. Gawlikowski, Konfucjański model państwa w Chinach, Warszawa 2009, s. 66.

${ }^{11} \mathrm{~K}$. Gawlikowski, Tajwan: spory o status wyspy i procesy transformacji, w: Azja Wschodnia na przełomie XX i XXI wieku. Stosunki międzynarodowe i gospodarcze, t. 2, pod red. K. Gawlikowskiego, M. Ławacz, Warszawa 2004, s. 47.

${ }^{12}$ Szerzej na ten temat zob. m.in. Tay-Sheng Wang, The Legal Development..., s. 531 i n.; Tsung-fu Chen, The Rule of Law in Taiwan, The Rule of Law. Perspectives from the Pacific Rim, Mansfield Dialogues in Asia, s. 108 i n.; Weng-Chen Chang, The Evolution of Administrative Adjudication in Taiwan: A Model of Judicial Cooperation, w: The Functional Transformation of Courts. Taiwan and Korea in Comparison, ed. by Jiunn-rong Yeh, Göttingen-Taipei 2015, s. 65 i n.

${ }^{13}$ L.E. Sitorus, Judicial Review of Administrative Action: Reflection on the Bank Century Bailout Policy, "Indonesia Law Review” 2016, no. 1, s. 81.

${ }^{14}$ P.H. Phan, Clinical Legal Education in China: In Pursuit of a Culture of Law and a Mission of Social Justice, "Yale Human Rights and Development Journal” 2005, vol. 8(1), s. 121. 
prawnej ${ }^{15}$. Tradycyjnie w Chinach kontynentalnych oraz na Tajwanie na pierwszym miejscu stawia się zazwyczaj interesy zbiorowości i grupy, do której dana jednostka przynależy, nie zaś samą jednostkę i jej prawa. Jednostkę postrzega się przede wszystkim jako cząstkę kolektywu, a nie autonomiczny podmiot. Takie spojrzenie odzwierciedla odmienną od zachodniej tradycję, której indywidualistyczne i personalistyczne podejście do człowieka ${ }^{16}$ dokonuje się stopniowo dopiero od początku XX w.

Różnica między zachodnią kulturą prawną a tradycjami chińskimi przejawia się także w odmiennym spojrzeniu na cele prawa. Zasadniczym celem jest sprawowanie przez państwo kontroli nad jednostkami, nie zaś wzmocnienie ich pozycji prawnej i ochrona przed ingerencją państwa. Należy przy tym zauważyć, że zachodnie pojmowanie prawa naturalnego, jako pierwotnego i niemogącego być derogowanym, jest obce tradycyjnej chińskiej myśli prawniczej ${ }^{17}$. Prawa jednostki są w Chinach traktowane jako prawa historyczne, co oznacza, że brane są pod uwagę przez pryzmat historycznych uwarunkowań i nie są traktowane ani jako uniwersalne, ani jako absolutne ${ }^{18}$. Oznacza to, że prawa te jako przyznawane przez państwo - mogą być przez państwo odebrane ${ }^{19}$.

Ponadto zauważyć trzeba, że w świetle założeń klasycznego konfucjanizmu jednostki nie są sobie równe, a idealne społeczeństwo powinno funkcjonować w ramach struktury hierarchicznej. W obrębie tej struktury jednostka ma do spełnienia swoją rolę i powinna jak najlepiej wypełniać nałożone na nią obowiązki ${ }^{20}$. Porządek społeczny możliwy jest do urzeczywistnienia jedynie wtedy, gdy każdy będzie znał swoje miejsce $\mathrm{w}$ hierarchii ${ }^{21}$. Prawo $(f \breve{a}$, 法) niweluje różnice $\mathrm{w}$ hierarchii społecznej, a to - zdaniem konfucjanistów okresu klasycznego - nie było pożądane. Przyjmowali oni, że system prawny nierzadko narzuca jednostce nienaturalne zachowania w stosunku do pełnionych w społeczeństwie tradycyjnych funkcji ${ }^{22}$.

${ }^{15}$ A. Skóra, Procedura wnoszenia..., s. 206.

${ }^{16}$ K. Gawlikowski, Pojmowanie jednostki w tradycji konfucjańskiej i jego konsekwencje dla życia politycznego w Azji Wschodniej, w: Indywidualizm a kolektywizm, pod red. A. Morstina, Warszawa 1999, s. 127; A. Skóra, Procedura wnoszenia..., s. 206.

${ }^{17}$ M. Kania, Wptyw konfucjanizmu..., s. 183.

${ }^{18}$ Ibidem, s. 194; A. Skóra, Procedura wnoszenia..., s. 206.

${ }^{19}$ L.E. Sitorus, Judicial Review..., s. 82; T. Ginsburg, Judicial Review in New Democracies Constitutional Courts in Asian Cases, Cambridge 2003, s. 12; A. Skóra, Procedura wnoszenia..., s. 206.

${ }^{20}$ M. Dargas, Idee i zasady..., s. 39 i n.

${ }^{21}$ Ibidem, s. 40.

22 Ibidem. 


\subsection{Podstawowe założenia konfucjanizmu a mediacja}

Ideał państwa, zdaniem Konfucjusza, zakłada zgodność myśli i działań jednostek tworzących określoną społeczność, co powoduje, że mediacja jawi się jako doskonałe narzędzie służące zapewnieniu harmonii na tym obszarze poprzez eliminację sporu między stronami w drodze wzajemnych ustępstw. Z tego względu w Chinach, na Tajwanie, a także $\mathrm{w}$ Japonii ${ }^{23}$ mediacja jest szeroko wykorzystywana. W państwach tych ważny jest bowiem - wynikający z założeń konfucjańskich - moralny nacisk na poszukiwanie harmonii w stosunkach międzyludzkich ${ }^{24}$. Wielu przedstawicieli chińskiej doktryny wskazuje właśnie na tradycję historyczną Chin jako wzór wykorzystywania pozaprawnych środków do rozwiązywania problemów prawnych ${ }^{25}$.

Popularność mediacji wynika także z tego, że ukształtowana przez setki lat nieufność jednostek do postępowań przed sądami nadal jest głęboko zakorzeniona w kontynentalnej tradycji prawnej Chin i nie jest łatwa do przezwyciężenia ${ }^{26}$. W przedrewolucyjnych Chinach mimo rozbudowanego systemu prawnego jednostki unikały inicjowania procesów sądowych ${ }^{27}$. Proces sądowy pojmowany był przez stulecia jako naruszenie obowiązujących zasad etycznych i filozoficznych oraz zaprzeczenie pożądanej harmonii w relacjach społecznych. Przyjmowano, że nie stanowi najwyższego osiągnięcia cywilizacji chińskiej, ale raczej niepożądaną konieczność. Wiele rodzin wprowadzało wewnętrzne, nieformalne zakazy prowadzenia postępowań przed sądem, by zachować swoje dobre imię. Zaangażowanie bowiem w postępowanie sądowe oceniane było jako skupienie się na własnych potrzebach jednostki, z pominięciem interesów społeczności, w jakiej ona funkcjonuje ${ }^{28}$. Na-

${ }^{23}$ Zob. szerzej m.in. S. Kakiuchi, Regulating Mediation in Japan: Latest Development and Its Background, w: New Developments..., s. 367 i n.

${ }^{24}$ M. Białecki, Mediacja w postępowaniu cywilnym, Warszawa 2012, s. 36, i cytowana tam literatura.

${ }^{25}$ T. Zhang, The Xinfang Phenomenon: Why the Chinese Prefer Administrative Petitioning over Litigation, "The Yale Law School Legal Scholarshiprepository” 2008, no. 7-8, s. 5-6, i cytowana tam literatura.

${ }^{26}$ C.X. Lin, Quiet Revolution: An Overview of China's Judicial Reform, "Asian-Pacific Law and Policy Journal" 2003, vol. 4, no. 2 (Summer), s. 280; A. Skóra, Kodyfikacja prawa o postępowaniu przed sadami administracyjnymi w państwach Azji, w: Idea kodyfikacji w nauce prawa administracyjnego procesowego. Ksiega pamiatkowa Profesora Janusza Borkowskiego, pod red. Z. Kmieciaka, W. Chróścielewskiego, Warszawa 2018, s. 287.

${ }^{27}$ M. Kania, Wptyw konfucjanizmu..., s. 189; A. Skóra, Procedura wnoszenia..., s. 213-214.

28 J.A. Cohen, Chinese Mediation on the Eve of Modernization, "California Law Review" 1966, vol. 54, iss. 3, s. 2. 
tomiast pozasądowa mediacja prowadzona przez zaufane jednostki, przeważnie z wyższych warstw społecznych, pozwalała chronić jej uczestników przed ujemną oceną społeczności (tzw. "utratą twarzy")29. W przedrewolucyjnych Chinach większość spraw była rozstrzygana przez ciała pozaprawne, takie jak osoby cieszące się prestiżem, głowy rodów i przedstawiciele lokalnych wspólnot. W czasach dynastii Qing, nawet jeśli strony prosiły sąd o rozstrzygnięcie sporu, miejscowy sędzia często zwracał stronom skargę i prosił je o skorzystanie z instytucji mediacji, aby zniechęcić je do postępowania sądowego ${ }^{30}$. W tym kontekście mediacja pozasądowa oraz - współcześnie - także przed sądem jawiła się i jawi więc jako lepszy, bo wynikający z miejscowej kultury i tradycji prawnej, sposób rozstrzygnięcia sporu.

\section{Mediacja w Chińskiej Republice Ludowej}

\subsection{Uwagi ogólne}

Jak już wskazano, mediacja w Chinach jest instytucją o długiej historii. Współcześnie o znaczeniu mediacji świadczy jej umiejscowienie w art. 111 Konstytucji Chińskiej Republiki Ludowej z dnia 4 grudnia 1982 r. ${ }^{31} \mathrm{~W}$ świetle tego przepisu komitety mieszkańców miast i wsi tworzą Ludowe Komitety ds. Mediacji, zajmujące się m.in. mediacją oraz prowadzeniem działań polubownych w sprawach cywilnych.

Warto wspomnieć, że Ludowy Sąd Najwyższy w publikowanych opiniach długo udzielał preferencji działaniom mediacyjnym w stosunku do adjudykacyjnego sposobu rozstrzygania sporów (tzw. polityka tiaojie youxian $)^{32}$. Opinie Ludowego Sądu Najwyższego służą w prak-

${ }^{29}$ "Utrata twarzy" stanowi pojęcie najbliższe polskim terminom takim jak "godność i "honor" i jest w Chinach i na Tajwanie bardzo poważnie traktowana. Zob. m.in. A.B. Kipnis, Producing Guanxi. Sentiment, Self and Subculture in a North China Village, Durham-London 1997, s. 148; E. Jastrzębska, Mediacja jako metoda rozwiązywania konfliktów. Mediacja w sprawach rodzinnych i opiekuńczych, „Fides et Ratio" 2014, nr 3(19), s. 165-166; A. Skóra, Kodyfikacja prawa..., s. 276-277.

${ }^{30}$ D. McFadden, Resolving Disputes in China Using Mediation, w: Business in China, ed. by M.J. Moser, wyd. 3, New York 2011, s. 7 i n.

${ }^{31}$ Tekst obowiązującej Konstytucji Chińskiej Republiki Ludowej z dnia 4 XII 1982 r. zob. http://biblioteka.sejm.gov.pl/konstytucje-swiata-chiny (dostęp: 9 VIII 2018).

${ }^{32}$ Ludowy Sąd Najwyższy sprawuje - obok sądów ludowych różnych szczebli, sądów wojskowych oraz innych sądów specjalnych - wymiar sprawiedliwości w ChRL. Zob. szerzej m.in. P. Chi Hin Chan, The Position..., s. 18. 
tyce orzeczniczej sądów wyjaśnieniu przepisów prawa; nie mają one jednak charakteru normatywnego ${ }^{33}$. Ludowy Sąd Najwyższy - zgodnie z Ustawą z dnia 15 marca 2000 r. o stanowieniu prawa - może przy tym dokonywać wiążącej wykładni ustaw i innych aktów normatywnych ${ }^{34}$. Współcześnie, tj. od ok. 2016 r., sąd ten de facto porzucił politykę preferowania "mediacji” na rzecz „znormalizowania” (changgui hua) proporcji między działaniami polubownymi a adjudykacyjnymi. Jednakże praktyka sądowa w sądach niższych instancji nadal daje nieformalne pierwszeństwo mediacji i arbitrażowi ${ }^{35}$.

\subsection{Mediacja ludowa}

Mediacja ludowa toczy się według przepisów Zhonghua Renmin Gongheguo Renmin Tiaojie Fa, czyli Ustawy z dnia 28 sierpnia 2010 r. - Prawo o mediacji ludowej ${ }^{36}$. Jest ona ważnym elementem systemu prawnego Chińskiej Republiki Ludowej. W jej świetle spory cywilne są rozstrzygane przez powołane zgodnie z prawem Ludowe Komitety ds. Mediacji. W świetle art. 34 p.m.l. Ludowe Komitety ds. Mediacji są zwykle tworzone przez komitety wiejskie i sąsiedzkie, mogą one również być powoływane przez przedsiębiorstwa (m.in. do rozstrzygania sporów w sprawach pracowniczych), jednostki instytucjonalne, miasta, dzielnice miast lub organizacje społeczne. Członkowie Ludowego Komitetu ds. Mediacji wybierani są spośród członków ludowego komitetu wiejskie-

${ }^{33}$ M. Dargas, Wjakim kierunku zmierza prawo Chińskiej Republiki Ludowej - ku systemowi common law czy ku kompleksowej kodyfikacji prawa?, "Gdańskie Studia Prawnicze” 2012, nr 1, s. 63.

${ }^{34}$ Skład i strukturę Najwyższego Sądu Ludowego określa Ustawa z dnia 1 VII 1979 r. o organizacji sądów ludowych Chińskiej Republiki Ludowej. Na jego czele stoi Prezes, który wybierany jest przez Ogólnochińskie Zgromadzenie Przedstawicieli Ludowych. Wykładnia dokonywana przez Ludowy Sąd Najwyższy ma postać ogólnych zasad, mających zapewnić właściwą analizę przepisów, wyjaśnić pojęcia nieostre, a także wypełniać ewentualne luki w prawie. Wykładnia sądu ma zastosowanie nie tylko do tej konkretnej sprawy, ale również do innych podobnych spraw w przyszłości. Pozostałe chińskie sądy nie są uprawnione do wydawania wiążących interpretacji, jednak wykładnia przez nie dokonywana może być uznana za quasi-prawotwórczą. Zob. szerzej M. Dargas, Wjakim kierunku..., s. 63, 65; M. Kania, Struktura konstytucyjnych organów państwowych Chińskiej Republiki Ludowej, "Acta Erasmiana” 2015, nr 9, s. 63.

${ }^{35}$ P. Chi Hin Chan, The Position..., s. 18.

${ }^{36}$ Ustawa z dnia 28 VIII 2010 r. Prawo o mediacji ludowej (dalej „p.m.l.") weszła w życie z dniem 1 I 2011 r., zob. http://www.npc.gov.cn/npc/xinwen/2010-08/28/ content_1593344.htm (dostęp: 9 VIII 2018). 
go lub ludowego komitetu sąsiedzkiego na spotkaniu mieszkańców wsi lub miast. Natomiast członkowie Ludowego Komitetu ds. Mediacji przedsiębiorstwa lub instytucji publicznej wybierani są przez ogólne zgromadzenie pracowników, przedstawicieli pracowników lub związków zawodowych.

Cele, jakie stawia im ustawodawca, to rozwiązywanie sporów pojawiających się między jednostkami oraz utrzymanie - istotnej dla społeczeństwa wychowanego w duchu filozofii konfucjańskiej - harmonii i stabilności społecznej.

Ustawodawca formułuje również kilka zasad, jakich powinny przestrzegać Ludowe Komitety ds. Mediacji. Mediator ma za zadanie przekonać strony sporu do osiągnięcia porozumienia, opierając swoje działania na równym ich traktowaniu i poszanowaniu ich woli (art. 2-3 p.m.l.). Działania komitetu powinny mieścić się $\mathrm{w}$ granicach przewidzianych przez ustawy i politykę państwa. Postępowanie przed Ludowymi Komitetami ds. Mediacji jest bezpłatne (art. 4 p.m.l.). Mediacja ludowa jest wspierana przez organy państwa, które zapewniają odpowiednie środki potrzebne do tego rodzaju "pośrednictwa” oraz premiują i wynagradzają członków Ludowych Komitetów ds. Mediacji i mediatorów (art. 6 p.m.l.).

Ludowy Komitet ds. Mediacji składa się z trzech do dziewięciu osób, z których jedna pełni funkcję przewodniczącego, dwie lub więcej zaś funkcje jej zastępców (art. 7-8 p.m.l.). Istnieje ustawowy obowiązek, by w skład komitetu wchodziły kobiety, a w miejscowościach wieloetnicznych - przedstawiciele mniejszości. Komitety te stanowią sui generis "uzupełnienie" chińskiego systemu wymiaru sprawiedliwości, jako niezależny podmiot umożliwiający rozwiązywanie sporów przez samych obywateli (art. 8 in fine p.m.l.).

\subsection{Mediacja i arbitraż w zakresie sporów wynikających z umów dotyczących gruntów rolnych}

Kolejnym aktem regulującym instytucję mediacji jest ustawa o mediacji i arbitrażu w zakresie sporów wynikających z umów dotyczących gruntów rolnych uchwalona w dniu 27 czerwca 2009 r. ${ }^{37}$ Ustawa ta ma na celu rozstrzyganie sporów wynikających z umów dotyczących gruntów rolnych i zarządzania tymi gruntami na obszarach wiejskich. Ma przy tym chronić uzasadnione prawa i interesy stron oraz uła-

\footnotetext{
${ }^{37}$ Ustawa z dnia 27 VI 2009 r. (dalej „u.m.a.”) weszła w życie 1 I 2010 r.
} 
twiać rozwój gospodarczy obszarów wiejskich, a także zapewniać stabilność społeczną (art. 1 u.m.a.). Rodzaje sporów podlegających polubownemu załatwieniu wylicza art. 2 u.m.a. Mediacja i arbitraż takich sporów powinny być oparte na zasadach jawności, słuszności i bezstronności, powinny być niekłopotliwe dla stron oraz skuteczne, a także prowadzone na podstawie rzeczywistego stanu faktycznego, zgodnie z prawem i moralnością społeczną (art. 5 u.m.a.). Ludowe komitety wiejskie lub komitety ludowe $\mathrm{w}$ miastach ( $\mathrm{w}$ ramach wielu chińskich miast znajdują się bowiem tereny wiejskie) powinny utrwalać wśród społeczności działania mediacyjne oraz zapewnić zainteresowanym stronom pomoc w zawarciu ugody (art. 7 u.m.a.). Strona może złożyć wniosek o mediację w formie ustnej lub pisemnej. Jeżeli wniosek zostanie złożony ustnie, odpowiedni komitet sporządzi adnotację zawierającą podstawowe informacje o wnioskodawcy, kwestii będącej przedmiotem sporu oraz przyczynach i terminie złożenia wniosku (art. 8 u.m.a.). Podczas pośredniczenia w rozstrzygnięciu sporu odpowiedni komitet ludowy zapewnia stronom prawo do bycia wysłuchanymi, informuje o odpowiednich przepisach prawa i zasadach polityki państwa i pomaga im osiągnać porozumienie poprzez cierpliwą perswazję (art. 9 u.m.a.). W przypadku gdy dojdzie do zawarcia porozumienia, odpowiedni komitet ludowy przygotowuje pisemną ugodę. Ugoda staje się skuteczna po jej podpisaniu przez obie strony lub umieszczeniu odcisków palców, a także złożeniu podpisu przez mediatora oraz opatrzeniu jej pieczęcią odpowiedniego komitetu mediacyjnego (art. 10 u.m.a.). Zasady powoływania i działania komitetów mediacyjnych regulują art. 12-17 u.m.a., skład komitetu - przepis art. 27 u.m.a., a przebieg postępowania mediacyjnego i jego utrwalenie - przepisy art. $30-48$ u.m.a.

\subsection{Mediacja i arbitraż w zakresie sporów pracowniczych}

Działania polubowne stosowane są również przy rozstrzyganiu sporów pracowniczych i związanych z nimi zagadnień oraz regulowane przez chiński Kodeks pracy z 1995 r., Kodeks postępowania cywilnego z 1991 r. oraz Wykładnię kilku zagadnień dotyczacych stosowania prawa w sporach pracowniczych dokonaną przez Ludowy Sąd Najwyższy w 2006 r. Obecnie ważnym aktem statuującym instytucję mediacji w tych sprawach jest Ustawa z dnia 29 grudnia 2007 r. - Prawo o arbitrażu i mediacji 
prawnopracowniczej Chińskiej Republiki Ludowej ${ }^{38}$. Jednym z celów ustawy jest uproszczenie rozstrzygania sporów pracowniczych. Po wystąpieniu sporu pracowniczego $\mathrm{w}$ przedsiębiorstwie pracodawca lub pracownik mogą ubiegać się o jego rozstrzygnięcie w drodze mediacji. Taka pomoc może być udzielona przez dowolny wyznaczony komitet mediacyjny działający w przedsiębiorstwie (tzw. „Wewnętrzny Komitet ds. Mediacji") lub przez określone władze państwowe, organizacje społeczne lub inne grupy poza przedsiębiorstwem (tzw. "Zewnętrzny Komitet ds. Mediacji"). Każdy Wewnętrzny Komitet ds. Mediacji przedsiębiorstwa musi składać się z członków reprezentujących pracownika i pracodawcę. Członek komitetu reprezentujący pracownika powinien być członkiem związku zawodowego lub przedstawicielem wybranym przez pracowników przedsiębiorstwa. Natomiast członka komitetu reprezentującego pracodawcę może wybrać zarząd przedsiębiorstwa (art. 10 p.a.m.p.). Ugoda zawarta w wyniku mediacji musi być sporządzona na piśmie i podpisana (lub opatrzona pieczęcią urzędową) przez pracodawcę, pracownika i mediatora. Tylko tak sporządzony dokument jest prawnie wiążący (art. 14 p.a.m.p.). W wymienionych w art. 16 cytowanej ustawy rodzajach sporów pracownik może zwrócić się do właściwego sądu ludowego o wydanie nakazu zapłaty w celu wyegzekwowania warunków ugody od pracodawcy, który nie dotrzymał jej warunków. Jednak uzyskanie nakazu zapłaty nie zawsze satysfakcjonuje stronę, gdyż - zgodnie z przepisami chińskiego Kodeksu postępowania cywilnego - po wniesieniu sprzeciwu przez drugą stronę nakaz zapłaty automatycznie traci moc. Każda ze stron może wówczas złożyć wniosek do odpowiedniego komitetu arbitrażowego rozstrzygającego spory pracownicze (art. 5 i 16 p.a.m.p.). Strony sporu pracowniczego mogą jednak od razu zdecydować się na arbitraż, omijając całkowicie etap mediacji (art. 5 p.a.m.p.). Spór pracowniczy musi być najpierw poddany mediacji, a dopiero potem arbitrażowi, m.in. jeżeli jedna ze stron nie wywiązała się z obowiązków określonych w ugodzie (art. 5 i 15 p.a.m.p.). Jeżeli strona nie zgadza się z wynikiem arbitrażu, ma $15 \mathrm{dni}$ na wniesienie środka prawnego do właściwego sądu ludowego (poza sporami podlegającymi rozstrzygnięciu w trybie przyspieszonym). Czas trwania postępowania arbitrażowego to $45 \mathrm{dni}$ od daty akceptacji przez

${ }^{38}$ Ustawa z dnia 29 XII 2007 r. Prawo o arbitrażu i mediacji w Chińskiej Republice Ludowej (dalej „p.a.m.p.”) weszła w życie z dniem 1 V 2008 r., zob. http://www.ilo.org/ dyn/travail/docs/488/Law\%20of\%20the\%20People's\%20Republic\%20of\%20China\%20 on\%20Labor-dispute\%20Mediation\%20and\%20Arbitration.doc (dostęp: 9 VIII 2018). 
komitet arbitrażowy wniosku o arbitraż. W sprawach skomplikowanych postępowanie może zostać przedłużone, ale nie dłużej niż o 15 dni. Jeśli komitet arbitrażowy nie dochowa terminu, strona może złożyć pozew bezpośrednio do sądu ludowego (art. 43 p.a.m.p.). Arbitrem w sporach pracowniczych może zostać tylko podmiot, który legitymuje się wiedzą prawniczą i doświadczeniem, m.in. posiada doświadczenie w pracy jako sędzia lub jest doświadczonym wykładowcą prawa. Arbitrem może być także podmiot, który ma wiedzę prawną $\mathrm{w}$ zakresie prawa pracy oraz minimalnie trzyletnie doświadczenie praktyczne (art. 6, 20 i 39 p.a.m.p.).

Pewne rodzaje sporów, określone w art. 47 ust. 1 i 2 w zw. z art. 50 p.a.m.p. (np. dotyczące uzyskania wynagrodzenia za pracę), rozstrzygane są $w$ trybie przyśpieszonym. W takim wypadku pracownik może odwołać się od wyniku arbitrażu do właściwego sądu ludowego w terminie 15 dni od otrzymania rozstrzygnięcia arbitrażowego. Natomiast pracodawca może odwołać się do sądu wyłącznie wtedy, gdy zaistnieje jedna z wymienionych $\mathrm{w}$ art. 49 p.a.m.p. okoliczności, m.in. gdy brak było jurysdykcji komitetu arbitrażowego, naruszono przepisy postępowania, w sprawie pojawiły się fałszywe dowody albo arbiter zażądał korzyści majątkowej lub ją przyjął lub naruszył prawo. W takich przypadkach sprawa toczy się już przed właściwym sądem ludowym wedle przepisów omawianej ustawy oraz Kodeksu postępowania cywilnego. Zasady przedawniania roszczeń określa art. 27 p.a.m.p.

\section{Rozstrzyganie sporów w postępowaniu administracyjnym i sądowoadministracyjnym}

\subsection{Uwagi ogólne}

Mimo popularności działań polubownych w Chinach mediacja jako instytucja normatywna nie jest znana w postępowaniach przed organami administracji ani w postępowaniu sądowoadministracyjnym.

Postępowanie administracyjne przed organami administracji w Chińskiej Republice Ludowej nie jest skodyfikowane i nie są obecnie podejmowane próby takich działań. Natomiast kodyfikacja procedury sądowoadministracyjnej sięga okresu przedrewolucyjnego ${ }^{39}$. Ustawa

${ }^{39}$ W 1909 r. przygotowany został projekt ustawy o Izbie Sądowoadministracyjnej, oparty na modelach: niemieckim, austriackim i japońskim. Przypominał jednak przede wszystkim ustawy japońskie z 1890 r.: ustawę nr 48 i ustawę o postępowaniach 
o postępowaniu administracyjnym uchwalona została w 1932 r., wprowadzając nowoczesny system środków zaskarżania służący eliminacji niezgodnych z prawem działań administracji. Jednak w Chinach kontynentalnych została uchylona w 1949 r. ${ }^{40}$ Od dnia 1 października 1990 r. obowiązuje ustawa o rozpatrywaniu sporów administracyjnych (Zhonghua Renmin Gongheguo Xingzheng Susong Fa) z dnia 4 kwietnia 1989 r. ${ }^{41} \mathrm{~W}$ tym układzie ogromne znaczenie praktyczne zyskała instytucja xinfang (zbliżona do naszej instytucji skarg, wniosków i petycji) jako sposób rozstrzygania przez chińską administrację potencjalnych sporów. Źródłosłowem terminu xinfang jest skrót od chińskich słów "listy i wizyty"42 (xin - listy, fang - wizyty) ${ }^{43}$, a sam termin uregulowany jest przez Ustawę z dnia 5 stycznia 2005 r. o listach i wizytach ${ }^{44}$ oraz $^{2}$ wydane przez Komitet Centralny Chińskiej Partii Komunistycznej i Radę Państwa Opinie dotyczace dalszego usprawniania działań zwiazzanych z rozpatrywaniem listów i wizyt w nowym okresie z $2007 \mathrm{r} .{ }^{45}$ Za pośrednictwem xinfang jednostki mają prawo zgłaszać swoje wnioski i petycje w róż-

administracyjnych w sprawach bezprawnych aktów wydanych przez organy administracyjne (ustawa nr 106). Tymczasowa konstytucja Chin z 1912 r. w art. 10 stwierdzała, że „obywatele mają prawo wnieść sprawę do sądu administracyjnego przeciwko działaniom urzędników naruszających ich prawa". W tym okresie przygotowano również projekt ustawy o sądowej kontroli administracji, zbliżony do regulacji japońskiej, zawierający jednak pewne oryginalne rozwiązania niemieckie, np. instytucję reprezentanta interesu publicznego (suzheng-shi) oraz zasadę określenia kognicji sądów na podstawie klauzuli generalnej. Pingzheng-yuan (czyli ustawa o organizacji sądów administracyjnych) funkcjonowała od marca 1914 r., a w 1928 r. została zastąpiona nową regulacja, zwaną Xingzheng-fayuan. Zob. m.in. A. Kość, Rozwój prawa w czasie Republiki Chińskiej, "Czasy Nowożytne" 2000, nr 9(10), s. 129; zob. też M. Dargas, W jakim kierunku..., s. 59-60; H. Kaneko, The Historical Evolution of Administrative Court System in Taiwan, "Krytyka Prawa” 2015, t. 7, s. 183-185; A. Skóra, Kodyfikacja prawa..., s. 287-288.

${ }^{40}$ J.P. Fa, Sh.Ch. Leng, Judicial Review of Administration in the People's Republic of China, "Case Western Reserve Journal of International Law" 1991, vol. 23, iss. 3, s. 448-449.

${ }^{41}$ Zob. szerzej m.in. A. Skóra, Kodyfikacja prawa..., s. 288 i n.

${ }^{42}$ X. Gao, J. Long, On the Petition System in China, "University of St. Thomas Law Journal" 2015, vol. 12, iss. 1 (Fall), s. 34.

${ }^{43}$ A. Skóra, Procedura wnoszenia..., s. 205.

${ }^{44}$ Akt ten obowiązuje od 1 V 2005 r. Regulations on Letters and Visits, adopted at the 76th Executive Meeting of the State Council on January 5, 2005, cyt. za: http://www. china.org.cn/e-news/news050428-3.htm (dostęp: 9 VIII 2018). Zob. szerzej A. Skóra, Procedura wnoszenia..., s. 207.

${ }^{45}$ X. Gao, J. Long, On the Petition..., s. 34. Idee te miały szersze tło. W latach dziewięćdziesiątych XX w. upowszechniły się w Chinach koncepcje "fuzji cywilizacji". Wyznawano pogląd, że Chiny powinny przejmować najwartościowsze elementy dorobku Zachodu i łączyć je z kultywowaniem najcenniejszych tradycji rodzimych. Podobnie powinien postępować Zachód: elementy zapożyczanych tradycji azjatyckich wzbogacą 
nych obszarach funkcjonowania państwa, m.in. w sprawach urbanistyki, ochrony środowiska czy zmiany konkretnego aktu prawnego ${ }^{46}$. Uważa się, że jest to jeden z najważniejszych sposobów rozstrzygania przez chińską administrację potencjalnych konfliktów społecznych i utrzymania porządku społecznego ${ }^{47}$. Xinfang wpisuje się zatem idealnie w hasło „harmonijnego społeczeństwa" (hexie shehui) ${ }^{48}$.

\subsection{Mediacja w Republice Chińskiej (Tajwan)}

Status prawnomiędzynarodowy Republiki Chińskiej podlegał radykalnym zmianom i nadal jest przedmiotem rozgrywek między mocarstwa$\mathrm{mi}^{49}$. Przed $1895 \mathrm{r}$. prawo na Tajwanie było zdominowane przez chińskie tradycje prawne. W 1895 r. rozpoczął się okres okupacji japońskiej (trwający do 1945 r.), który charakteryzował się recepcją japońskich rozwiązań prawnych oraz dorobku prawnego państw zachodnich na tyle silna, że w literaturze przedmiotu pisze się o tendencji „odwrotu od tradycyjnego prawa chińskiego ku prawu zachodniemu"50. Od początku okresu okupacji organy samorządu lokalnego, zgodnie z chińską prawną tradycja, mogły pełnić rolę mediatora w sporach cywilnych ${ }^{51}$. Ustawa z 1904 r. o mediacji w sporach cywilnych przewidywała, że wszelkie te spory mogą być rozstrzygane przez przewodniczącego lokalnego samorządu, a jeśli uda się osiągnąć kompromis, strony nie mogą ponownie wnieść pozwu, ale jedynie ubiegać się o przymusową realizację ugody przez organy samorządu ${ }^{52}$. Pracownik organu administracji jako mediator nalegał, wykorzystując swój autorytet i prestiż, by strony zaakceptowały przedstawioną przez niego propozycję rozstrzygnięcia sporu, a tym samym faktycznie skorzystały z możliwości rozstrzygania sporów cywilnych bez poddania ich kognicji sądu ${ }^{53}$.

jego dziedzictwo i pozwolą mu uwolnić się od własnych braków, zob. K. Gawlikowski, Konfucjański model..., s. 67.

${ }^{46}$ X. Gao, J. Long, On the Petition..., s. 36; A. Skóra, Procedura wnoszenia..., s. 212.

${ }^{47}$ Ibidem, s. 34; J.P. Fa, Sh.Ch. Leng, Judicial Review..., s. 450.

${ }^{48}$ K. Gawlikowski, Konfucjański model..., s. 60, 66; A. Skóra, Procedura wnoszenia..., s. 212.

${ }^{49}$ K. Gawlikowski, Tajwan..., s. 1.

50 Tay-Sheng Wang, The Legal Development..., s. 559.

${ }^{51}$ Ibidem, s. 557.

${ }^{52}$ Ibidem.

${ }^{53}$ Ibidem. 
Po objęciu rządów przez Chińską Partię Narodową (Kuomintang, KMT) wprowadzono chiński system mediacji w powiatach (縣, xiàn) ${ }^{54}$. Ustawa o mediacji w powiatach z 1955 r. zakładała, że Komitet ds. Mediacji (złożony raczej z miejscowej ludności, nie zaś z urzędników) mógł prowadzić mediację $\mathrm{w}$ każdym sporze cywilnym i w tych sprawach karnych, które wszczynano na wniosek pokrzywdzonego ${ }^{55}$. Jeżeli osiągnięto kompromis, sąd był uprawniony (a od $1982 \mathrm{r}$. jest zobowiązany) dokonać oceny ugody pod względem prawnym, strony zaś mogą wystąpić o jej przymusową egzekucję ${ }^{56}$. Początkowo ten rodzaj mediacji cieszył się popularnością, gdyż - jak już wspomniano - Tajwańczycy wahali się korzystać z sądów w celu rozstrzygania sporów cywilnych, ponieważ nie było to zgodne z chińską tradycją. Obawiali się ponadto, że japońscy sędziowie nie rozstrzygną ich sprawy właściwie, gdyż nie znają ich języka ojczystego i zwyczajów ${ }^{57}$. Nie bez znaczenia był także czas oczekiwania na rozstrzygnięcie sprawy przez sąd oraz koszty postępowania, które mogły być bardzo wysokie. Co ciekawe, władze japońskie chętnie promowały mediację administracyjną w celu zmniejszenia liczby spraw sądowych i niechętnie zwiększały inwestycje w sądownictwo ${ }^{58}$. Jednak od lat dwudziestych XX w. mieszkańcy Tajwanu coraz częściej poddawali swoje spory kognicji sądu, a tendencja ta wzrosła w okresie rządów KMT ${ }^{59}$.

Współcześnie na Tajwanie znane są trzy rodzaje tzw. alternatywnych metod rozstrzygania sporów, obejmujące zarówno prawo cywilne, jak i karne, tj. mediacja, ugoda sądowa i arbitraż. Najogólniej, mediacja i ugoda sądowa mają zastosowanie w sprawach drobniejszych, podczas gdy arbitraż wykorzystuje się w celu polubownego rozstrzygnięcia w skomplikowanych sprawach finansowych, handlowych czy dotyczących własności intelektualnej. W sprawach karnych możliwe jest obniżenie wymiaru kary, jeżeli oskarżony doprowadzi do zawarcia ugody z pokrzywdzonym. W świetle Kodeksu rodzinnego mediacja w sprawach rodzinnych jest obowiązkowa. Porozumienie mediacyjne

\footnotetext{
${ }^{54} \mathrm{Na}$ Tajwanie funkcjonują rady powiatów (xian yihui), starostowie (xianzhang), a także rady miejskie (miast, miast na prawach powiatów oraz miast wydzielonych), prezydenci, rady gminne i wójtowie. Zob. J. Rowiński, W. Jakóbiec, System konstytucyjny i przedstawicielski Tajwanu, Warszawa 2015, s. 127.

55 Tay-Sheng Wang, The Legal Development..., s. 557.

${ }^{56}$ Ibidem.

${ }^{57}$ Ibidem, s. 558.

${ }^{58}$ Ibidem, s. 557.

${ }^{59}$ Ibidem.
} 
zawarte w sądzie lub poza nim przed lokalnym Komitetem ds. Mediacji ma moc równą wyrokowi sądu.

Postępowanie mediacyjne prowadzone przez sąd przewiduje tajwański Kodeks postępowania cywilnego z dnia 26 grudnia 1930 r. ${ }^{60}$, który $\mathrm{w}$ art. 403 wylicza rodzaje spraw, jakie powinny zostać poddane działaniom polubownym ( $w$ dużej mierze są to sprawy związane $z$ ustaleniem prawa własności i innych praw rzeczowych - art. 77 ust. 20 i art. 403 wspomnianej ustawy). Po otrzymaniu pozwu sąd w pierwszej kolejności prowadzi postępowanie mediacyjne. $W$ przypadku niepowodzenia mediacji postępowanie będzie toczyło się już w trybie zwykłym. Kodeks postępowania cywilnego stanowi ponadto, że jeżeli dana sprawa nie podlega obowiązkowej mediacji, każda strona może również wystąpić o jej przeprowadzenie (art. 404 ustawy). Zachętą jest też niewątpliwie możliwość złożenia przez powoda wniosku o zwrot dwóch trzecich kosztów sądowych w przypadku zakończenia mediacji zawarciem ugody (art. 420 ust. 1 ustawy).

\section{Podsumowanie}

Przedstawione rozwiązania instytucjonalne i prawne pozwalają na stwierdzenie, że rozwiązania chińskie w zakresie mediacji, zarówno w Chinach kontynentalnych, jak i na Tajwanie, nie są wynikiem recepcji instytucji funkcjonujących w państwach zachodnich. Państwa te dumne są bowiem ze swej kultury prawnej, jakkolwiek dorobek prawny państw zachodnich oraz najważniejsze pomniki prawa są tam znane i analizowane. Trzeba również pamiętać, że charakterystyczne dla Chin kontynentalnych i Tajwanu jest odmienne od europejskiego spojrzenie na prawa jednostki i jej pozycję w społeczeństwie, a co za tym idzie - na rozwiązywanie sporów między jednostkami. Mediacja służy w Chinach i na Tajwanie nie tylko do rozstrzygania sporów między jednostkami, lecz także do utrzymania porządku społecznego, i ta druga rola - jakkolwiek brzmi to dziwnie dla europejskiego czytelnika - postrzegana jest jako pierwszoplanowa.

Ostatnimi laty w chińskim porządku prawnym charakterystyczne jest także silne odwoływanie się - podczas tworzenia prawa - do założeń tzw. nowego konfucjanizmu. Można zatem stwierdzić, że podstawowe

${ }^{60}$ Tekst tajwańskiego Kodeksu postępowania cywilnego zob. http://jirs.judicial.gov. tw/eng/FLAW/FLAWDAT01.asp?lsid=FL001362 (dostęp: 9 VIII 2018). 
uregulowania w zakresie mediacji wywodzą się z miejscowej kultury i tradycji oraz dostosowane są do miejscowych standardów. Powoduje to, że mediacja i arbitraż są w tych państwach bardzo popularne, zwłaszcza w sprawach cywilnych i sporach prawnopracowniczych. Ustawodawca zachęca strony do polubownego rozstrzygania sporów, m.in. poprzez redukcję kosztów postępowania czy obniżenie wymiaru kary (w sprawach karnych). W obu państwach mediacja stanowi alternatywę dla postępowania sądowego albo funkcjonuje w jego ramach jako szczególne rozwiązanie procesowe, nie odbierając jednocześnie jednostkom prawa do sądu. Mediacja nie funkcjonuje jednak jako rozwiązanie normatywne na gruncie postępowań przed organami administracji publicznej; nie przewiduje jej też Ustawa z dnia 4 kwietnia 1989 r. o rozpatrywaniu sporów administracyjnych. W tym układzie ogromne znaczenie praktyczne zyskała instytucja xinfang (uregulowana przez Ustawę z dnia 5 stycznia 2005 r. o listach i wizytach), wykorzystywana m.in. jako sposób rozstrzygania przez chińską administrację potencjalnych sporów.

W nauce pojawiają się jednak także głosy krytyczne, stwierdzające, że mediacja, w szczególności mediacja przed sądem, może być postrzegana jako narzędzie służące utrzymaniu harmonii społecznej kosztem sprawiedliwości proceduralnej ${ }^{61}$. Trzeba jednak zauważyć, że idea sprawiedliwości proceduralnej jest wytworem zachodniej nauki prawnej, znanej i analizowanej w obu państwach chińskich, ale obcej ich rodzimej kulturze prawnej. Zapewne $z$ tego względu nie jest wysuwana jako pierwszoplanowy postulat podczas prac legislacyjnych w zakresie mediacji. Europejskiemu badaczowi trudno przewidzieć, w jakim stopniu chińskie rozwiązania prawne pozostaną wierne liczącej ponad dwa tysiące lat tradycji, a w jakim poddadzą się wpływom normatywnych rozwiązań zachodnich $\mathrm{w}$ procesie postępującej globalizacji.

\section{MEDIATION IN THE PEOPLE'S REPUBLIC OF CHINA AND IN THE REPUBLIC OF CHINA (TAIWAN)}

\section{S u m mary}

The objective of this research paper is to explore and analyse mediation in the People's Republic of China and in the Republic of China (Taiwan). The author also investigates the historical, philosophical and social origin of mediation and its development since the Han Dynasty. Mediation has a long tradition in China, and

\footnotetext{
${ }^{61}$ P. Chi Hin Chan, The Position..., s. 18.
} 
its importance can be traced back to the philosophy of Confucianism. Nowadays mediation is known as the key to resolving all disputes and linking it to the "harmonious society" political doctrine. There are currently a few types of mediation practices in China: mediation by People's Mediation Committees outside the court, judicial mediation in civil disputes and minor criminal cases inside the court, mediation and arbitration of rural land contract disputes or mediation and arbitration in labour disputes. The importance of mediation is demonstrated by Article 111 of the Constitution of the People's Republic of China, which provides that "People's Mediation Committees are a working committee under grassroots autonomous organisations - the Residents Committee and the Villagers Committee - whose mission is to mediate civil disputes." The Committees and the courts should also popularise, through mediation and arbitration, the laws and the policy and educate citizens to abide by the laws and respect universally accepted morals. As can be seen, owing to the government's guidance on mediation procedures the number of cases settled through mediation has markedly increased. The statistics show that the parties not only resolve their dispute but are also willing to resort to mediation again. The high success rate of mediation is, among other things, due to the fact that it is a safe and neutral process, and the mediators' role in facilitating resolution does not impose a solution. Another advantage of mediation is speed and effectiveness as well as a reduction of costs. This article also discusses the Taiwanese experience with mediation, as well as its development. To sum up it may be said that mediation in the People's Republic of China and in the Republic of China (Taiwan) functions well and is increasingly winning trust of citizens.

Keywords: mediation - arbitration - China - Taiwan - Confucianism 